Ragg, Sascha, Ketzer und Recht. Die weltliche Ketzergesetzgebung des Hochmittelalters unter dem Einfluss des römischen und kanonischen Rechts

\title{
Uwe Brunn
}

\section{OpenEdition}

1 Journals

Édition électronique

URL : http://journals.openedition.org/ifha/1655

DOI : 10.4000/ifha. 1655

ISSN : 2198-8943

Éditeur

IFRA - Institut franco-allemand (sciences historiques et sociales)

Référence électronique

Uwe Brunn, «Ragg, Sascha, Ketzer und Recht. Die weltliche Ketzergesetzgebung des Hochmittelalters unter dem Einfluss des römischen und kanonischen Rechts », Revue de I'IFHA [En ligne], Date de recension, mis en ligne le 01 janvier 2008, consulté le 22 septembre 2020. URL : http:// journals.openedition.org/ifha/1655; DOI : https://doi.org/10.4000/ifha.1655

Ce document a été généré automatiquement le 22 septembre 2020.

(C)IFHA 


\title{
Ragg, Sascha, Ketzer und Recht. Die weltliche Ketzergesetzgebung des Hochmittelalters unter dem Einfluss des römischen und kanonischen Rechts
}

\author{
Uwe Brunn
}

Le livre de S.R. se présente comme une synthèse sur le déploiement du droit savant dans la lutte antihérétique et son instrumentalisation par les représentants du pouvoir temporel au Moyen Âge central.

L'auteur insiste tout d'abord sur la continuité du traitement de la dissidence religieuse par le pouvoir romain : les hérétiques de l'époque post-constantinienne étaient exposés aux mêmes mesures que les chrétiens (et manichéens) du IIIe s., persécutés pour s'être opposés au culte impérial. Au lieu de mettre en place un nouveau droit, la législation antihérétique chrétienne réaffirme un droit ancien : interdiction aux dissidents de se réunir et de prêcher, perte de droits civiques, incarcérations, confiscations, amendes, bannissements, travaux forcés. En même temps, le droit romain dresse un pont juridique entre magie et hérésie, considérant les deux comme crimes de lèse majesté, dignes de la peine capitale.

Entre la rédaction du codex Theodosianus et celle du codex Iustinianus, les dispositions prises contre l'hétérodoxie s'affinent et se durcissent, notamment à l'égard des manichéens. Le codex Theodosianus passe sans discontinuité dans la tradition juridique médiévale. S.R. montre dans quelle mesure il entre dans les leges au Haut Moyen Âge : l'hérésie continue à jouer un rôle dans les lois wisigothiques, elle disparait des autres codes barbares ; la magie, en revanche, garde une place importante dans la majorité de ces textes. Les capitulaires carolingiens, tout en perpétuant la double action législative contre l'hérésie et la magie, s'ancrent, plus que les codes barbares, dans la législation synodale de l'Église, mais la place de celle-ci reste marginale.

$\mathrm{Au}$ fur et à mesure que l'Église se renforce institutionnellement, elle s'approprie le thème de l'hérésie et met en place une nouvelle législation, dans un premier temps peu 
systématique, surtout conciliaire. Cette période de tâtonnement juridique s'achève avec le Décret de Gratien. En droit canon, l'hérésie est désormais soumise à une casuistique savante aboutissant à l'acceptation de règles générales relatives au traitement des hérétiques. Parallèlement, l'exploitation du code Justinien par les juristes du XIIe s. met pleinement à la disposition des souverains médiévaux les concepts d'hérésie employés par les empereurs romains de l'Antiquité, leur permettant ainsi de s'approprier un discours ancien de criminalisation de l'hérésie, dans lequel apparaissent, au premier plan, l'infamie et le crimen maiestatis.

Ces évolutions juridiques vont de pair avec une nette politisation de l'hérésie, surtout au XIIIe s. Tout d'abord en Italie où papes et empereurs utilisent la législation antihérétique comme une arme contre la dissidence politique. Leurs dispositions entrent dans le droit royal allemand, mais aussi dans les « miroirs » et le droit urbain de différentes régions germaniques. En France, une riche législation conciliaire s'était développée dès le XIIe s., obligeant les pouvoirs laïcs à prendre position. Dans le contexte de la croisade albigeoise cependant, les conciles sont relayés par le pape et ses légats, puis par le roi et ses baillis, soutenus, à partir des années 1230, par les inquisiteurs. Certaines dispositions prises pour la France méridionale se répercutent alors dans les coutumes de la France du Centre. Dans le royaume d'Aragon, la législation antihérétique reste dans la tradition du droit romain, mais subit aussi l'influence des textes hispaniques de la pax et treuga Dei où la rupture de la paix était considérée comme crime de lèse majesté. En Castille l'hérésie ne joue qu'un rôle marginal : dans les grands textes de droit produits dans ce royaume, elle doit sa place essentiellement aux reprises du Liber Iudiciorum wisigothique ; une nouvelle législation antihérétique castillane émerge seulement au seuil du XIVe s. avec les Siete partidas composées sous Ferdinand IV. L'Angleterre enfin constitue une exception. Entre l'Assise de Clarendon de 1166 et la composition du Miroir de Justices vers 1290, en effet, les Plantagenêt n'ont pas légiféré sur les hérétiques.

L'ouvrage de S.R. se situe dans la ligne de quelques travaux anciens plus circonscrits. Analysant les mesures proposées à l'encontre de la dissidence, il s'abstient de prendre part aux débats récents relatifs aux stratégies institutionnelles et sociales qui animent l'activité des législateurs antihérétiques.

Uwe Brunn (Université de Montpellier III) 